\title{
IMPLEMENTATION OF ORGANIZATIONAL CHANGES IN ESTONIAN COMPANIES
}

\author{
Ruth Alas \\ Estonian Business School, Lauteri 3, 10114 Tallinn, Estonia \\ E-mail:ruth.alas@ebs.ee \\ Received 18 June 2007; accepted 30 October 2008
}

\begin{abstract}
Both the popular press and academic literature tend to consider organizational change as a step-by-step process leading to success. This paper examines the suitability of the theory that guides the implementation of change at company level for organizations in countries in transition. The author's surveys, conducted in 137 Estonian companies in 2001 and 121 in 2005, show that the main focus of Estonian managers has been on initiating change and much less attention paid to assessing the process of change and making modifications and consolidating improvements. A process model of change for countries in transition has been proposed.
\end{abstract}

Keywords: process of change, trigger event, core process, support processes.

\section{Introduction}

The post-communist transformation provides settings in the process of being demolished that are very different in their characteristics within which discontinuities are more fundamental and change is less constrained by institutional frameworks. Scholars of organizational change have tended to have their focus restricted, because of the normal socio-economic context in which they work, by changes in public opinion, legal conditions and similar discontinuities within the social structures (Clark and Soulsby 1999). During economic transformation, the challenge has been to internalize a new type of organizational behaviour in order to operate successfully under unfamiliar conditions. Learning, both institutional and individual, and the ensuing corporate changes are seen as a prerequisite for the success and survival of organizations.

According to Edwards and Lawrence (2000), the emergent change to processes in transforming countries can only be truly understood by examining the constitutive practices of individuals and groups at the local micro levels of the economic system. Research in countries going through transformation has shown that the transfer of knowledge from market-economy practices often fails because of institutional and cultural tensions and conflict (Clark and Geppert 2002).

There are no commonly accepted theories of change worked out for these countries, and so the author has applied concepts and insights embedded in the organizational experience of Western countries as the basis for the research and has combined these theories with empirical findings collected from the country in transition. In doing so, this also provides fresh ways of thinking about organizational change as a further contribution to international business research. The research question is, which modifications should be done in Western process theories, in order to analyze the implementation process of change in different economic environment.

Arguably, one of the most successful transitions from a socialist economy to a market economy took place in Estonia (Leimann et al. 2003). Estonia was until 1991 part of the Soviet Union with a centrally planned economy. In the 90s, the Estonian economy was changed 
for a free-market economy. Already in 1995, according to opinions held by managers, there were signs of stability (Liuhto 1999). The Heritage Foundation ranked Estonia, according to an overall index of economic freedom, among the freest countries in the world: placed in the fourth place in 2002 (Rajasalu 2003: 18). On 1 May 2004, Estonia joined the European Union. This makes Estonia suitable for studying the implementation process of organizational change.

The paper starts with theoretical framework for dealing with process of organizational changes. This is followed by empirical results from Estonian organizations. The author compares the implementation of changes according to data from two surveys in Estonian organizations: in 2001 and 2005. The author suggests a process model for analyzing changes in Estonian organizations.

\section{The theoretical framework}

Dopson and Neumann (1998) have perceived change as a necessary evil for survival in the context of uncertainty. In this article an organization is defined as a complex system that produces output in the context of an environment, an available set of resources and a history (Nadler \& Tushman 1989). Organizational change has been defined as a planned response to pressures from the environment and forces inside an organization.
Descriptive research that only assesses the structure may fail to see underlying causes, whereas analyzing the dynamics of the process appears to provide powerful prescriptive insights (Nutt 2003). Jick (1993) has generalized that both the popular press and academic literature tend to consider organizational change as a step-by-step process leading to success.

Depending on the context there exist at least ten different definitions for the word 'process' (Fletcher et al. 2003). The process of change could be seen as an individual activity or connected activities or subprocesses bringing about the processing of a task (Fletcher et al. 2003); or as a sequence of dependent events (Balle 1995); or a logical, related, sequential (connected) set of activities (Harrington et al. 1997). Pettigrew and Whipp (1991) have viewed change management as an analytical, educational (learning) and political process.

The basic model developed by Lewin (1989) consists of three steps: unfreezing, moving, and refreezing. Lewin's model is often quoted, but sometimes without the warning that freezing at the new level should be a deliberate planned objective. Merely reaching a new level is no guarantee of its permanency, even in the short term (Foster 1989).

The author compared the process theories of change from different theorists based on Lewin's (1989) threestep model (Table 1).

Table 1. A comparison of steps in process theories of change

\begin{tabular}{|c|c|c|c|}
\hline Lewin (1989) & Unfreezing & Moving & Refreezing \\
\hline $\begin{array}{l}\text { Mohrman's and } \\
\text { Cummings's (1989) }\end{array}$ & Laying the foundation/Designing & $\begin{array}{l}\text { Implementing } \\
\text { and assessing }\end{array}$ & \\
\hline $\begin{array}{l}\text { Tichy and Devanna } \\
(1986)\end{array}$ & $\begin{array}{l}\text { Recognizing need for change/ } \\
\text { Creating vision }\end{array}$ & & $\begin{array}{l}\text { Institutionalizing } \\
\text { change }\end{array}$ \\
\hline $\begin{array}{l}\text { Cummings and Worley } \\
\text { (1997) }\end{array}$ & $\begin{array}{l}\text { Motivating change/Crea-ting a vision/ } \\
\text { Developing political support }\end{array}$ & $\begin{array}{l}\text { Managing } \\
\text { the transition }\end{array}$ & $\begin{array}{l}\text { Sustaining } \\
\text { momentum }\end{array}$ \\
\hline Judson (1991) & $\begin{array}{l}\text { Analysing and planning the change/ } \\
\text { Communica-ting the change/ } \\
\text { Gaining acceptance of new behaviours }\end{array}$ & $\begin{array}{l}\text { Changing from the } \\
\text { status quo to a desired state }\end{array}$ & $\begin{array}{l}\text { Consolidating and } \\
\text { institutionalizing } \\
\text { the new state }\end{array}$ \\
\hline $\begin{array}{l}\text { Goss, Pascale, Athos } \\
\text { (1998) }\end{array}$ & $\begin{array}{l}\text { Assembling a critical mass of key } \\
\text { stakehol-ders/Doing an organisational } \\
\text { audit/Creating urgency }\end{array}$ & Harnessing contention & $\begin{array}{l}\text { Engineering } \\
\text { organisational } \\
\text { breakdowns }\end{array}$ \\
\hline Greiner (1975) & $\begin{array}{l}\text { Pressure on top management/ } \\
\text { Intervention at the top/Diagnosis } \\
\text { of problems }\end{array}$ & $\begin{array}{l}\text { Invention of new } \\
\text { solutions/Experimentation } \\
\text { with new solutions }\end{array}$ & $\begin{array}{l}\text { Reinforcement } \\
\text { of positive results }\end{array}$ \\
\hline $\begin{array}{l}\text { Beer, Eisenstat and } \\
\text { Spector (1990) }\end{array}$ & $\begin{array}{l}\text { Mobilize commit-ment/Develop } \\
\text { a shared vision/Foster consensus }\end{array}$ & Spread revitalisation & $\begin{array}{l}\text { Institutionalise } \\
\text { revitalisation/Monitor } \\
\text { and adjust strategies }\end{array}$ \\
\hline Kotter (1998) & $\begin{array}{l}\text { Establishing a sense of urgency/Forming } \\
\text { a po-werful coalition/Creating a vision/ } \\
\text { Communicating the vision }\end{array}$ & $\begin{array}{l}\text { Empowering/ } \\
\text { Short-term wins/ } \\
\text { Consolidating improvements }\end{array}$ & $\begin{array}{l}\text { Institutionalizing } \\
\text { the new approaches }\end{array}$ \\
\hline
\end{tabular}


Table 1 indicates that all authors have turned most of attention to unfreezing phase.

The 10 keys to successful change management (Pendlebury et al. 1998) could be also considered as process theory, but this includes also different kind of activities than process models referred in Table 1. Defining the vision, mobilizing and delivering could easily be added to Table 1. At the same time handling power issues, handling the emotional dimension, communicating actively, training and coaching are taking place during several stages. For implementation of changes in such quickly changing environment as Estonia is, the second type of activities is very important as well. Therefore there is need to consider in analysis of implementation of change not only activities given in Table 1, but also the second group of activities and this changing environment as the reason for the change.

Therefore a triangular of elements of change process is proposed as a theoretical framework for analyzing changes in Estonian organizations of this article. The three crucial elements of the change process are the following:

- the trigger event,

- steps in core process (formed from steps which should be in consequence) and

- support processes (activities taking place during several stages of core process).

\section{Trigger events}

It is usually changes in the external environment that trigger a process to start. Events represent the changing state of the world (Davis 2001). A trigger event is an event whose occurrence starts a task or a workflow (Fletcher et al. 2003). There could be a single event that triggers the process to start or multiple trigger events.

\section{Core process}

A major process is a process that usually involves more than one function within the organizational structure and its operation has a significant impact on the way the organization functions (Harrington et al. 1997). Core processes are strategically important business processes (Scheer 2000). These processes form the sequential steps - the steps have some order - one should be started before the next. For example, before vision creation the need for change should be determined. Most of steps in Table 1 belong to core processes. The disadvantage of models, dealing only with this kind of steps is, that these models do not emphasise enough activities, which help to implement these steps.

\section{Support processes}

Support processes take place during almost the whole change process and are inevitable for the implemen- tation process as a whole. Support processes provide inputs that allow the core activities to take place. For example, in order to implement changes successfully, several support processes are needed to identify resistance as an obstacle to overcome (Armenakis and Bedeian 1999). Three elements - information, communication and training - have been pointed out as part of a definition of change management by Hammer and Stanton (1995). People have to be informed about changes, then their feedback is required and intense communication starts. Finally, people have to be trained to be successful in the new business process environment (Kirchmer and Scheer 2003).

Also enablers and change drivers could be classified under support processes. An enabler is an organizational facility/resource that makes it possible to perform a task, activity or process - enhancement, self-management or education (Harrington et al. 1997).

As changes in organizational structures bring with them a redistribution of power and influence in regard to decision making, groups and individuals that are negatively affected by a reorganization, in the sense that their impact on decision making is reduced, typically are opposed to the change (Katz and Kahn 1978). Handling power issues helps to remove obstacles in the implementation process. By mobilizing, the dynamics for change is created; by catalyzing, the structure of the project is created and run; by steering, actions are kept on course (Pendlebury et al. 1998).

\section{Empirical study in Estonian organizations}

\subsection{Methodology}

In 2001, structured interviews about the implementation of organizational changes were conducted with members of top management teams from 137 Estonian companies (Alas and Sharifi 2002). These changes took place in the $1990 \mathrm{~s}$, during a period of social transience in Estonian society. In 2005, interviews were again conducted with members of top management teams from 106 Estonian organizations about changes implemented since joining the European Union. The interview questions were similar during both interviews, although some questions were added in 2005 .

In this paper the author analyses the answers to questions about steps in the process of changes only. There were several questions about the process of change. First respondents were asked: "How did the implementation of organizational changes take place? Which steps were taken in the process of implementation of organizational change? Please describe in as much de- 
tail as possible. With each activity specify if it occurred as a result of some earlier event or constantly during the whole process of change."

The next question was: "How was the process of change managed? Who handled it, was there a specially formed task force to manage the process? Did the management style differ from the ordinary management style or not? Did it change within the process of change?"

Also activities connected with resistance to change helped to indicate steps in the process of change. Respondents were asked: "Did you meet resistance to change? What did your company do to overcome resistance to change? What did the management originally do to eliminate resistance? What did it do to overcome the existing resistance? Which management activities were the most efficient ones?"

Lessons learned were identified with questions "Which were the most difficult issues during the implementation of changes?" and "What did you learn from implementation of these changes? What would you do differently in the future?".

In order to evaluate the dynamics, the results from 2005 are compared to the results from the interviews in 2001. Examples from the interview transcripts have been used to indicate activities taken.

\subsection{Results}

\section{The steps in the process of change}

The steps in the process of change in Estonian organizations were analysed on the basis of the steps in the most popular model of change process, Kotter's (1998) model (Table 2).
There was a problem in interpreting some steps from this model. The term 'empowerment' for instance, was not used by Estonian managers and it was also hard to find something about consolidating improvements. At the same time respondents mentioned involvement of their employees after vision creation and the creation of a suitable climate for the implementation of their vision. So, these replaced Kotter's steps.

Results in Table 2 confirm the theorists' position, that most of attention goes to unfreezing stage. In 2001 creating vision was the most popular step, followed by creating sense of urgency and communicating of vision. In 2005 creating sense of urgency dominated, followed by creating the vision and creating short-term wins. The last item shows that in 2005 moving stage got already more attention than in 2001. Also institutionalizing the new approaches has got much more attention in 2005. It indicates learning, taking place in Estonian companies. Employee involvement and communicating vision have increased during the last 5 years.

\section{Core process}

Taking into account results of current two surveys: steps implemented and a need to unlearn, core process of implementation of changes in Estonian organizations consists of the following steps: Determining the need for change and unlearning; Creating a vision; Communicating the vision; Implementing change and unlearning; and finally Institutionalizing change and learning.

Steps are illustrated with part from different interviews. Determining the need for change and unlearning: " $A t$ first we realised that it was necessary to introduce significant changes in the company in order to stay in

Table 2. Steps in implementation of the change process in Estonian companies (\% of companies)

\begin{tabular}{|c|c|c|}
\hline Step in change process & 2001 & 2005 \\
\hline \multicolumn{3}{|l|}{ Unfreezing } \\
\hline Establishing sense of urgency & 56 & 80 \\
\hline Forming a coalition or team & 24 & 26 \\
\hline Creating a vision & 69 & 70 \\
\hline Communicating the vision & 34 & 41 \\
\hline \multicolumn{3}{|l|}{ Moving } \\
\hline Creating a suitable climate & 18 & 18 \\
\hline Employee involvement & 23 & 44 \\
\hline Creating short-term gains & 16 & 58 \\
\hline \multicolumn{3}{|l|}{ Finishing change } \\
\hline Institutionalizing the new approaches in organizational culture & 21 & 36 \\
\hline
\end{tabular}


competition. As a result of long discussions, we identified the most essential fields in need of change".

Creating a vision: "There was no clearly specified vision in the hotel chain, yet the pinned map of the Baltic Sea region could have been considered one, because it showed the development of new projects and the continued activity of already established hotels. The new strategy was considered, a vision from the point of view of development - 15 new hotels by the year 2007".

Communicating the vision was needed: "It was necessary to work out a way to sell the new vision to our employees, and then look further together about how to take this to the clients". It took place in the following ways: "The vision, mission and goals were introduced to the employees of the merged companies at a joint meeting. The event in Latvia lasted for the whole weekend and all the employees from the Baltic countries had been invited. In order to better bring the people together there was a one-day sporting event". Also "The company organised a conference and asked partners to attend from countries where the new system already works, so that they would speak about the advantages of the new system".

During implementation celebrations were used: "The end of a stage was celebrated by a topic related cake or a joint sporting event".

For institutionalizing change and learning "An employee handbook was compiled, which outlined all the procedures and relations between the work of different units and the quality of the final service offered to the client".

\section{Support process}

Following are the examples from interviews how activities supporting the core process were performed in Estonian companies.

Support process with most critical importance is communication. Extracts from interview: "To make communication more efficient, several formal and informal channels of information were established. Among the formal channels were the Intranet, i.e. the in-company home page, in-company newspaper, informative meetings to all the employees, a scheme of meetings, strategic seminars for the leaders of the major functional divisions, the division of managers' working time between different sub-institutions, regular meetings with trade union representatives". The next: "The chairman of the board started organising regular informative meetings that were meant for all the employees. At those meetings he explained the reasons for the change and the goals of the company. These meetings were also aimed at creating a feeling of working "side by side", i.e. the employees worked not only to achieve their personal goals but to achieve the company goals through their contribution". Or "It is necessary to talk about everything, and if there is nothing to be said, this has to be made clear as well" and "It was explained to every employee, how each employee personally can benefit from this change".

Delivering the change includes the day-to-day actions for realizing the vision, and also creating detailed plans for change: "The detailed plans made in each department define the schedule, the person responsible and the results of each stage".

To catalyse the change, special structures were created: "The workgroup for designing the new working procedures involved consultants and employees from several functions. It was important that the employees represent the different stages of the process and they already have sufficient working experience in the company".

With the use of steering tactics, actions were kept on course: "The implementation of changes was monitored via weekly meetings and informative briefings. The deadlines were generally met. In case any problems appeared with the deadlines, an immediate plan of action was made to resolve the situation".

Handling emotions was necessary because "Emotions were rather different within the company and the confused employees had to go through periods of hesitation, questions and fear"; or in more detailed way: "The organization went through several emotional stages - confusion and loss of understanding, fear about the future and finally enthusiasm about the challenges opening up with the new solutions". Managers organised - "preparation of interim reports in order to find out the problems, what disturbed people the most and what they were afraid of". Informing employees helped to handle emotions: "Before we informed the people there was a lot of electricity, ignorance and dread in the air. After being informed about the changes, people became scared, but this feeling passed rather quickly". Also, "using an outplacement programme helped to avoid excessive emotions and prepared those people who were to be made redundant for competition in the labour market." Additionally, "In order to reduce stress people were given cinema and theatre tickets".

Handling power issues helped to remove obstacles in the implementation process: "the "old time" middle management were replaced". 
Managers realised that "it was necessary to work out a way to sell the new vision to our employees and then look further together about how to take it to the clients". In some cases, internal marketing was used: "The company decided to value its employees and sales agents as the most invaluable clients (internal clients). Such a novel approach appeared a positive surprise to the employees".

Different mobilizing activities were created for achieving employee involvement: "The employees were given an example, on the basis of media supplied facts about the activities of competitors, to illustrate how their changes had helped in the improvement of service quality and thereby increased their competitiveness" or, "In the process of restructuring, the heads of the new units received the right to form their own teams, make the budget, etc".

Changes raised the need for training: "When changes started appearing within the concern and in the surrounding environment, we started with training the managements of the companies. All the company managers passed a two-stage training session at Company University " $X$ in Change". The training session dealt with the whole process of change by beginning with supplying information to the employees and clients and finishing with the probable dangers and tackling them".

\section{Lessons learned}

The respondents were asked about the most difficult issues during the implementation of change and what they would do differently in the future. It appeared that in 2001 the biggest difficulty according to $32 \%$ of the respondents was in unlearning what they had done before. In 2005 this number was even bigger. In $200124 \%$ of respondents and $26 \%$ in 2005 found that employees did not realize how necessary the changes were for the company.

If in 2001 twenty-two percent of the respondents would plan and prepare changes more carefully, then in 2005 already 53\% indicated need for more careful preparation (Table 3). If in 2001 another $22 \%$ would explain the essence of the changes to their employees in greater detail and give more information in a more practical way, this figure has increased also to $30 \%$ in 2005 . Also, involvement of employees has increased from $16 \%$ in 2001 to $30 \%$ in 2005 . All these $\%$-s indicate importance of support processes during implementation of changes.

\section{Conclusions}

As changes management has been considered as a business process like any other that a company carries out (Abolhassan 2003), the author applied process management in analyzing changes in Estonian organizations.

The most difficult during both surveys, in 2001 and 2005 was to unlearn what they had done before. Also, it was not easy to make employees realize how necessary the changes are. At the same time learning had taken place between two surveys and in 2005 managers had turned more attention to almost every step in the change process. Managers had learned how important employee involvement was and all activities connected with preparing and mobilizing people for changes.

The reason why changes are undertaken in the organizations is the need to increase value of organization. Therefore the author applies Porter's value chain model (Porter 1985) as a base for creating model for implementation of changes in Estonian organizations (Fig. 1).

Trigger event for changes in Estonian companies was the change in status of Estonia at the beginning of the 1990s. After leaving the centrally planned Soviet Union in 1991 and losing the Soviet market, Estonian companies had to reorient to the European market. In order to be able to compete in a tight Western market instead of the empty Soviet market, Estonian companies had to introduce Western standards (instead of the standards of the Soviet State) and increase efficiency. In the Soviet period, the state was responsible for guaranteeing work for everyone. Therefore enterprises were internally overstaffed and passive, work places were oversecured and attitudes to work were far from

Table 3. Lessons learned ( $\%$ of companies)

\begin{tabular}{lcc}
\hline What managers would do differently & 2001 & 2005 \\
\hline Plan and prepare changes more carefully & 22 & 53 \\
\hline Explain the essence of the changes to their employees in greater detail & 22 & 30 \\
\hline Involve employees on every level of the organization from the early stages of the changes & 16 & 30 \\
\hline Pay more attention to establishing goals, process and subgoals & 14 & 16 \\
\hline
\end{tabular}




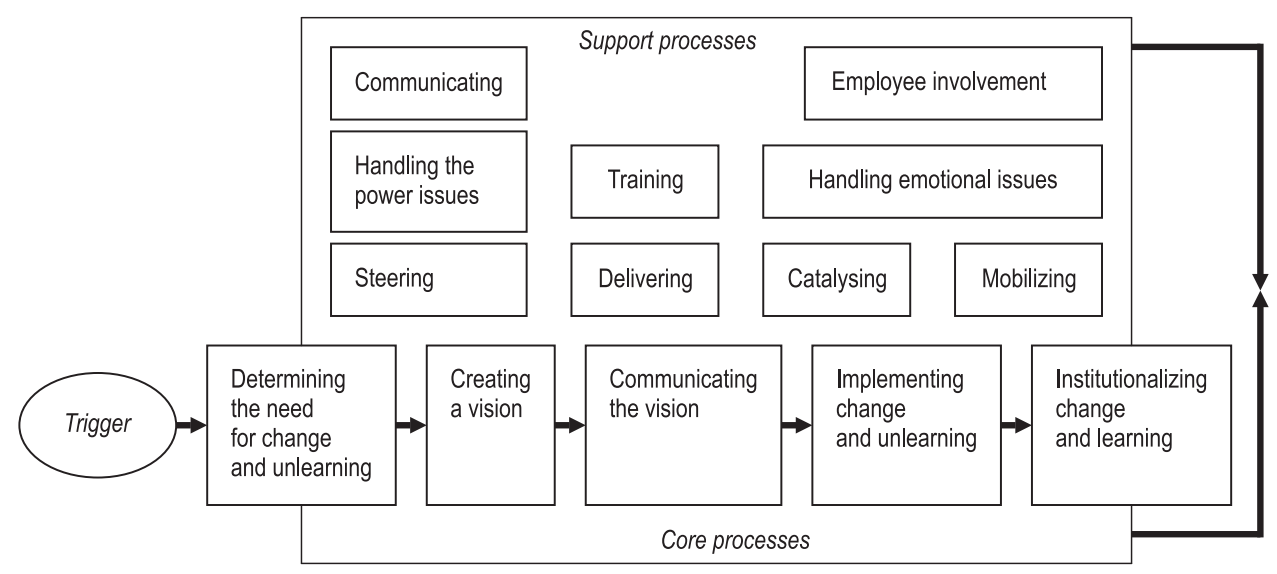

Fig. 1. The process model for the implementation of organizational change

ideal (Liuhto 1999: 16). People had to adapt to competition on labour market and obtain different attitudes toward work. In 1997 Estonia started to negotiate with the European Union and this was the trigger event for new changes needed for entering the EU.

Core process consisted of 5 steps. The author of this study divided Lewin's (1989) first step into three parts and added emphasis to the need for unlearning past practices and changing attitudes. The new steps in the change model for Estonian companies are: (1) Determining the need for change and unlearning; (2) Creating a vision; (3) Communicating the vision; (4) The implementation of change and unlearning; and (5) Institutionaliszing the change and learning.

During the first step, managers scan the environment and compare the actions and processes in the company with similar activities in leading companies in the same field. This may then lead to recognising the need for organisational change. At the same time, managers should analyse their assets concerning know-how and then they may recognise the need for new know-how, attitudes and behaviours in the organisation in order to accomplish this new vision.

During the second step, managers need to create a vision of the people with the new expertise, attitudes, and behaviours. They should then ascertain how large the gap is between the existing attitudes of employees and the desired attitudes and behaviours. This will help to determine the need for unlearning. A vision of the future state of the company should then be created on the basis of these observations and the current resources of the company. It could be useful for the managers to conduct force-field analysis to determine the force of resistance as an obstacle to change, unlearning old and learning new.

During the third step different activities should be taken in order to communicate the created vision to all employees, existing and prospective clients and partners. Managers should make sure that the employees have really understood the organisation's business objectives.

The fourth step, implementing change, is similar to Lewin's (1989) second stage. The author has added implementing unlearning. Plans made during the earlier stages are carried out. Changes to the structure, operations and processes are implemented. Employees unlearn old skills and learn new skills and behaviours. Learning by making mistakes takes place. The ability to use collaborative skills and teamwork is very important at this stage. There is a growth of open communication and the willingness among employees to develop themselves. The manager's role here is to support the personal development of employees.

The fifth step is for evaluating the results of the change effort and for consolidating positive results. Successful changes in behaviours and processes are written down as rules and procedures, and changes are institutionalized. Institutionalizing learning means storing all the knowledge obtained in the organisation. The information system should enable the storage of knowledge so that after people leave, their knowledge remains within the organisation. It should also make information available to all the people making decisions or conducting analyses. At the same time it should be stated in procedures as well, that these changes are not final - the organisation remains flexible and open to new changes, and unlearning and learning have become core activities of the company.

Senge (1997) has mentioned that human beings are more complex than we often assume. They both fear and seek change. People don't resist change. They resist being changed. In order to achieve that people feel, that instead of being changed by someone else, they are active part of these changes themselves and these 
changes are what they themselves want, different activities supporting core process are needed.

In totalitarian societies people's choices were constrained because of the use of coercive forms of political and economic control (Eagly and Chaiken 1993). In contrast, a free market economy with a democratic political system presented people with many choices. This difference at the societal level has also carried through into organizations. The management style in the totalitarian society was autocratic and trained employees to fulfil the managers' directives without question. People were not involved in decision-making. There were well developed hierarchies, where people expected answers to problems to be decided by someone higher up, and even managers were inclined to rely on aid and direction from higher authority, this was one of the outstanding features of the Soviet era in Estonia (Üksvärav 2001).

Support processes should make sure that everything possible is being done to achieve employee commitment to objectives of change process. This is only possible if employees can see a connection between the company's objectives and their own objectives. The use of a collaborative setting of missions and strategies could help. The creation of the conditions and motivation for unlearning and learning by creating open-minded and positive attitudes toward risk-taking is useful.

During all five steps of the organisational change process the company's management has a central role. A participatory style of leadership and choosing management practices, which help to create a learning environment, form a great part in the success of the change process. More people should be involved in the process of discussion at the beginning stage, and this would make it relatively easier to introduce changes later. The processes should be described and mapped immediately. This would make it possible to approach the changes rather more process centered than function centered. The relationship between core and support services should be described. The company should try to preserve a positive internal climate and create a belief in the employees as part of the results. It is essential that people learn and develop through the changes, and that I talk more to my subordinates, ask for solutions to problems and give them more freedom in their activities. It is necessary to talk to the employees more at different levels in order to avoid the spreading of news in the form of gossip and the probable resulting confusion.

In conclusion, the survey results indicate that to implement organisational changes more successfully, man- agers of Estonian companies should turn more of their attention to unlearning habits and thinking patterns that people obtained during previous stages of economic and social development. This unlearning process and the replacement of these patterns with others more suitable for dynamic organisations in an extremely rapidly changing global environment, is the central issue in the process of change in Estonian companies.

\section{References}

Abolhassan, F. 2003. The change management process implemented at IDS Scheer, in Scheer, A. W. et al. (Eds.). Business Process Change Management: ARIS in Practice. Springer, 15-22.

Alas, R.; Sharifi, S. 2002. Organisational learning and resistance to change in Estonian companies, Human Resource Development International 5(3): 313-331.

Armenakis, A. A.; Bedeian, A. G. 1999. Organizational change: A review of theory and research in the 1990s, Journal of Management 25: 293-315.

Balle, M. 1995. The business process re-engineering action kit: A five days plan to redesign your processes. London: Kogan Page.

Clark, E.; Geppert, M. 2002. Management learning and knowledge transfer in transforming societies: Approaches, issues and future directions, Human Resource Development International 5(3): 263-277.

Clark, E.; Soulsby, A. 1999. Organisational change in postcommunist Europe: Management and transformation in the Czech Republic. London: Routledge.

Davis, R. 2001. Business process modelling with ARIS: A practical guide. New York: Springer-Verlag.

Dopson, S.; Neumann, J. E. 1998. Uncertainty, contrariness and the double-find: Middle managers' reactions to changing contracts, British Journal of Management 9: 53-70.

Eagly, A. H.; Chaiken, S. 1993. The psychology of attitudes. Forth Worth, TX: Harcourt Brace Jovanovich College Publishers.

Edwards, V.; Lawrence, P. 2000. Management in Eastern Europe. Basingstoke: Palgrave.

Foster, M. 1989. The historical perspective, in McLennan, R. (ed.). Managing Organizational Change. Prentice Hall, 34-38.

Fletcher, A. N.; Brahm, M.; Pargmann, H. 2003. Workflow management with SAP WebFlow: A practical manual. Springer.

Hammer, M.; Stanton, S. 1995. The reengineering revolution. Glasgow.

Harrington, H. J.; Esseling, E. K. C.; Harm van Nimwegen. 1997. Business process improvement workbook. McGrawHill. 
Jick, T. D. 1993. Managing change. Cases and concepts. Homewood, IL: Irwin.

Katz, D.; Kahn, R. L. 1978. The social psychology of organizations. Second edition. New York: Wiley.

Kirchmer, M.; Scheer, A. W. 2003. Change management Key for business process excellence, in Scheer, A.W. et al. (Eds.). Business Process Change Management: ARIS in Practice. Springer, 1-14.

Kotter, J.P. 1998. Leading change: Why transformation efforts fail, Harvard Business Review on Change. A Harvard Business Review Paperback, 1-21.

Leimann, J.; Santalainen, T. J.; Baliga, R. B. 2003. An examination of the dynamics of transformation of Estonian state-owned enterprises toward a free-market orientation, in Ennuste, Ü. and Wilder, L. (Eds.). Essays in Estonia Transformation Economics, Estonian Institute of Economics and Tallinn Technical University, 49-69.

Lewin, K. 1989. Changing as three steps: Unfreezing, moving, and freezing of group standards, in French, W. L.; Bell, C. H. Jr.; Zawacki, R. A. (Eds.). Organizational Development. Theory, Practice, and Research. Third edition. Homewood, IL: Irwin. $87 \mathrm{p}$.

Liuhto, K. 1999. The organisational and managerial transformation in turbulent business environments - managers' views on the transition of their enterprise in some of the European former Soviet republics in the 1990s. Publications of the Turku School of Economics and Business Administration, Series A-9.
Nadler, D. A.; Tushman, M. L. 1989. Organizational frame bending: Principles for managing reorientation, The Academy of Management, Executive Magazine 3(3): 194-204.

Nutt, P. C. 2003. Implications for organizational change in the structure process duality, in Woodman, R. W.; Pasmore, W. A. (Eds.). Research in Organizational Change and Development. Greenwich, CT: JAI Press 14: 147-193.

Pendlebury, J.; Grouard, B.; Meston, F. 1998. The ten keys to successful change management. John Wiley \& Sons.

Pettigrew, A. M.; Whipp, R. 1991. Managing change for competitive success. Oxford and Chambridge, MA: Blackwell.

Porter, M. E. 1985. Competitive advantage. New York: Free Press.

Rajasalu, T. 2003. Indicators of economic freedom and economic structure as determinants of growth and convergence in enlarging EU and priorities for Estonia, in Ennuste, Ü. and Wilder, L. (Eds.). Essays in Estonia Transformation Economics. Estonian Institute of Economics and Tallinn Technical University, 7-32.

Scheer, A. W. 2000. ARIS - business process modelling. Third edition. Springer.

Senge, P. M. 1997. The fifth discipline. The art and practice of the learning organisation. Century business.

Üksvärav, R. 2001. Management culture in Estonia: Past and present features, in Suominen, A. (Ed.). Searching for the Boundaries of Business Culture, Publications of the Turku School of Economics and Business Administration. Series C-1, 103-120. 